\title{
STRATEGI KONSERVASI KEBUDAYAAN LOKAL YOGYAKARTA
}

\author{
Amiluhur Soeroso* \\ Y. Sri Susilo \\ STIE Pariwisata API Yogyakarta dan Universitas Atma Jaya Yogyakarta
}

\begin{abstract}
The purpose of this paper is assessing conservation strategy of Yogyakarta local culture to muffle attacking globalization of cultural economic and cultural industry. We do looking for effectual strategy to develop cultural tourism based on creativity sense. We first identify important factors that confound the physic and entity culture using factor and cluster analysis. Following this, we apply expert choice to enact the strategy. We conclude that important factors for the conservation of culture are introducing the Javanese eco-culture to society early on, revitalizing the ritual tradition and conserving the traditional dance and music. In addition, we propose the policy brief in order to become the important reference of cultural tourism development. The important policies are giving cognitive, affective and conative education to people, and reanimating traditional jackstraws.
\end{abstract}

Keywords: strategy, conservation, culture, cultural economic, cultural tourism, Yogyakarta

\section{Pendahuluan}

Kebudayaan memiliki arti luas yang melibatkan pikiran, karsa dan hasil karya manusia yang tidak berakar pada nalurinya sehingga dapat dicetuskan oleh manusia setelah mengalami proses belajar. Konsep ini menyangkut hampir seluruh kegiatan manusia di dalam mengarungi kehidupannya. Unsur universal kebudayaan yang ada di seluruh dunia (Koentjaraningrat 2004) meliputi: (1) religi, (2) organisasi kemasyarakatan, (3) pengetahuan, (4) bahasa, (5) mata pencaharian, (6) kesenian, dan (7) teknologi dan peralatan. Namun, pengembangan kebudayaan asli yang sebenarnya dapat dilakukan di Indonesia, hanya pada satu unsur dari tujuh unsur kebudayaan tersebut, yaitu kesenian (Koentjaraningrat, 2004), karena unsur yang lain mengalami akulturasi. Berdasarkan pemikiran tersebut maka titik fokus upaya pelestarian kebudayaan di Yogyakarta adalah pada unsur kebudayaan yang dapat dikembangkan dan dapat diunggulkan agar menjadikan Yogyakarta sebagai pusat pariwisata kebudayaan terkemuka di tahun 2020.

Dalam konteks ini Yogyakarta kecuali sebagai "kota pelajar" juga menjadi daerah tujuan wisata penting di Indonesia yang bertumpu pada sumberdaya ekonomi kreatif (cultural economic) yaitu kebudayaan, terutama pada kekhasan sejarah, pusat pendidikan, dan berbagai kesenian seperti perayaan adat dan pesta rakyat. Dengan ditunjang karya senibudaya, Yogyakarta dapat menjadi tempat ideal untuk pengembangan pariwisata budaya dan etnik (Smith 1977), dengan menekankan observasi terhadap ekspresi dan gaya hidup masyarakat yang eksotik. Pariwisata budaya meliputi kunjungan ke industri dengan obyek kuliner, kesenian, baik seni rupa (bangunan dan upacara tradisional, tata rias, pementasan tari) maupun seni suara (kerawitan, mancapat). Seni rupa meliputi seni arsitektural bangunan, seni rias (terutama seni pakaian kebaya yang telah menjadi kebudayaan nasional dengan seni batik dan lurik), seni kerajinan (kulit atau wayang). Selain itu, seni suara yang ada di 
Yogyakarta meliputi seni vokal dan instrumental (karawitan dan macapat) yang tergabung dengan seni tari. Ruang lingkup keduanya berkembang pesat.

Namun, proses globalisasi yang cepat telah mengubah konstelasi kebudayaan. Usaha ekonomi yang memproduksi barang kebudayaan (cultural goods) sebagai pendukung atraksi dan amenitas pariwisata budaya banyak dikuasai asing. Sebagai contoh, kuliner asing seperti hamburger McDonald mengalahkan geplak atau jajan pasar, seni kerawitan dan kebaya termarjinalisasi instrumen musik dan busana bangsa Eropa, sedangkan kuda lumping dikalahkan break dance; bahkan permainan anak-anak seperti gobak sodor dan dakon sudah lama punah dilumpuhkan computer game dan play station. Upaya revitalisasi kebudayaan lokal agar unggul bersaing dengan mancanegara dalam industri kreatif (cultural industry) sudah berulang-kali dilakukan tetapi hasilnya belum signifikan. Sayangnya, pariwisata budaya pun selama ini justru dikembangkan secara universal dan uniformitas tanpa melihat keanekaragaman yang dimilikinya. Ketidak-berhasilan upaya tersebut ditengarai pula karena ketidak-tahuan ataupun ketiadaan strategi yang tepat dalam melestarikan budaya lokal sehingga arah pencapaiannya bias.

Padahal pengetahuan terhadap strategi konservasi kebudayaan adalah penting karena berhubungan dengan kemitraan, pelestarian lingkungan, pembelajaran dan pengembangan pendidikan yang kekal, peningkatan kualitas hidup dan memperlihatkan nilai terbaik yang dimiliki masyarakat. Strategi pelestarian akan mendorong pembangunan pariwisata berbasis kebudayaan masyarakat yang kuat dengan menciptakan infrastruktur pembangunan berkelanjutan untuk menghadapi laju globalisasi pertumbuhan industri kreatif, meningkatkan kualitas dan peluang akses terhadap ruang, acara dan aktivitas serta mengatasi hambatan partisipasi komunitas pada kebudayaan. Strategi ini memberikan pendekatan yang koheren dan terpadu dalam aspek manajemen warisan budaya, agar masyarakat dan para wisatawan masih melihatnya di masa yang akan datang, juga memberikan pandangan kepada pemegang otoritas untuk dapat mengambil tindakan untuk mempertahankannya (Ferguson dan Scadden 2004; Haley 2001). Sementara itu, strategi ini juga akan mendorong keterlibatan masyarakat agar mereka dapat menghormati warisan budayanya sendiri dan menghadapi tantangan dengan kepercayaan diri, sekaligus mempromosikan, mengembangkan, membaginya dan menjadi subyek kebudayaan lain. Oleh karena itu, tujuan penelitian ini adalah menemukan strategi yang organik dan tepat sasaran sehingga dapat diimplementasikan secara faktual untuk melestarikan kebudayaan lokal agar menjadi mainstream "Yogyakarta sebagai pusat pariwisata budaya".

\section{Landasan Teori dan Pengembangan Hipotesis}

Industri kebudayaan adalah industri berbasis kreatif yang berorientasi masa depan. Di dalam industri ini termaktub cetakan (termasuk batik) dan percetakan, multimedia, audio-visual dan produksi sinematografis, kerajinan tangan dan disain, kemudian arsitektur bangunan, seni visual dan pertunjukan, olah-raga, musik, pabrikan alat musik, periklanan dan pariwisata budaya (UNESCO 2007). Menurut Howkins (2007), ekonomi kreatif adalah kegiatan ekonomi dengan input dan output-nya gagasan atau kreativitas orisinil pelaku seni. Dengan demikian industri kreatif mengandalkan kreativitas, keterampilan serta talenta individu yang memiliki kemampuan meningkatkan taraf hidup dan peluang bekerja melalui penciptaan (gagasan) dan eksploitasi hak kekayaan intektual. 
Namun, era globalisasi telah mempengaruhi hampir semua aspek di masyarakat, termasuk di antaranya aspek kebudayaan baik berupa nilai-nilai (values) yang dianut, maupun psikologis. Dalam proses globalisasi berbagai budaya lokal lenyap ternafikan oleh kekuatan homogenisasi barat, akibat gerakan partikularitas keberagaman budaya lokal berkembang ke dalam konstelasi kultur yang baru (Steger 2002). Dewasa ini proses globalisasi mencapai puncak perkembangannya dengan melibatkan seluruh dunia; dari perspektif kultural kuat ditandai terutama karakteristik bias western-isasi dan imperialisme budaya. Tehranian (Mintohardjo 2007) secara metaforik menyebutkan bahwa abad ke-20 sebagai abad kematian yang direncanakan (a century of death by design) dalam pengertian merosotnya nilai-nilai dasar akibat dampak negatif proses globalisasi.

Kini mulai muncul kesadaran individu dan kelompok etnik, sub-etnik atau suku bangsa dalam menghadapi gejala uniformitas globalisasi. Penolakan, antiglobalisasi atau reaksi balik atas globalisasi yang disebut sebagai proses lokalisasi, "glokalisasi" (globalisasi plus lokalisasi) atau tribalization. Menurut Robertson (Featherstone 1990) arus kultural global sering membangkitkan berbagai bentuk budaya lokal. Pluralisasi dunia ketika proses lokalitas melahirkan berbagai tanggapan kultural yang unik terhadap kekuatan global. Hasil yang dicapai bukanlah meningkatnya homogenisasi kultural melainkan glokalisasi yaitu interaksi yang kompleks antara global dan lokal yang bercirikan peminjaman budaya (cultural borrowing). Interaksi tersebut berujung penggabungan hasrat homogenisasi dan heterogenisasi yang disebut sebagai hibridisasi atau kreolisasi, berupa pencampuran budaya dalam ekonomi kreatif seperti dilakukan pada musik, film, pertunjukan, bahasa dan bentukbentuk ekspresi simbolik lainnya. Proses glokalisasi merupakan upaya mencari titik temu atau upaya kompromistis antara tetap mengembangkan proses globalisasi di satu pihak dan semakin meningkatkan proses lokalisasi yang muncul dimana-mana sebagai reaksi balik di pihak yang lain.

Untuk itu, keanekaragaman budaya lokal Yogyakarta baik berujud (tangible) maupun tidak berujud (intangible), yang telah menjadi hak masyarakat perlu dilindungi. Pengemasan properti kebudayaan sebagai produk industri kebudayaan, haruslah memperhatikan nilai tradisionalnya seperti nilai eksistensi, warisan, religius, sejarah dan lain-lain yang berbasis pada masyarakat lokal.

Globalisasi industri kebudayaan berimbas pula pada pariwisata budaya, sehingga ekowisata menjadi sebuah strategi penting. Ekowisata secara luas pengertiannya selain melakukan konservasi, juga merespon ekologi, dan sosial-ekonomi-budaya (Merric dan Hunt 1998: 37; Sirakaya dan McLellan 1998: 42-43). Pariwisata ramah lingkungan atau ekowisata bukan hanya bentuk perjalanan ke alam saja, namun diinterpretasikan lebih luas meliputi konservasi budaya (Ayala 1996: 46). Kesuksesan pengelolaan ekowisata selain memberi nilai tambah pada masyarakat, juga akan melindungi sumberdaya alam dan melestarikan nilai sosialkebudayaan, termasuk tempat bersejarah.

Perluasan definisi ekowisata melahirkan konsep eko-ekonomi dan eko-budaya yang mengintegrasikan organisme, manusia dan lingkungannya dengan tujuan memperbaiki kebiasaan dan perilaku buruk pengelolaan ekologi termasuk dampak terhadap lingkungan dan eksternalitasnya (Gossen 1993: 2-3). Ekobudaya fokus pada eksistensi pengetahuan tradisional dan mendukung penggunaan bahan baku lokal, sedangkan eko-ekonomi mmenjadikan perekonomian lebih memperhatikan ekologi dengan tujuan memuaskan kebutuhan saat ini tanpa membahayakan kebutuhan generasi di masa depan (Brown 2001: 
77-78). Perekonomian dapat berkelanjutan hanya jika memperhatikan prinsip dan budaya memelihara ekologi; bila tidak, akan menyebabkan penurunan dan secepatnya runtuh.

Dengan demikian, kebudayaan adalah salah satu faktor yang menentukan keatraktifan sebuah daerah tujuan wisata. Elemen kebudayaan masyarakat merupakan sebuah kompleks yang merefleksikan cara mereka hidup, bekerja dan berkarya. Pariwisata budaya meliputi seluruh aspek perjalanan di tempat orang belajar tentang setiap cara hidup dan pemikiran orang lain. Oleh sebab itu, pariwisata menjadi sarana promosi penting dalam hubungan ekonomi, kebudayaan dan kerjasama internasional. Sebaliknya, pembangunan faktor-faktor kebudayaan di dalam sebuah bangsa merupakan sarana untuk meningkatkan sumberdaya penarik wisatawan. Di banyak negara, pariwisata diasosiasikan dengan kebijakan "hubungan kebudayaan", untuk mempromosikan bukan hanya pengetahuan dan pengertian tetapi juga citra yang menarik dari sebuah bangsa di antara bangsa lain (Goeldner dan Ritchie 2003). Salurannya melalui elemen kebudayaan seperti keramah-tamahan, rancangan arsitektur, kuliner, kerajinan tangan, dan karakteristik cara hidup (way of life) masyarakat. Namun, atraksi kebudayaan harus ditampilkan dengan cara yang cerdas dan kreatif. Oleh karena itu di sini terlihat sebuah kebutuhan yang besar untuk meningkatkan keanekaragaman kebudayaan (cultural diversity).

Sebagai dasar pijakan konservasi budaya lokal digunakan kisi-kisi pengambilan keputusan dengan hirarki kebijakan, strategi dan taktik atau implementasi (Gambar 1-1). Kebijakan mensintesiskan variasi dari prinsip-prinsip optimasi dengan kebijakan publik dan proses legal; atau dapat diartikan sebagai keputusan yang didisain untuk deal dengan masalah sosial yang ada, sehingga dapat diambil tindakan tertentu yang sesuai (Nagel 1982). Sementara itu, manajemen strategi adalah proses upaya untuk menyatukan rencana dan sumberdaya yang dimiliki baik dengan lingkungan eksternal dan internal (Langabeer II 1998). Tujuannya meraih keunggulan dan menciptakan posisi aman dengan melakukan efisiensi, kontrol kualitas, inovasi dan memperhatikan tanggapan konsumen; sasarannya adalah kelestarian pengembangannya (Lee dan Snepenger 1992). Adapun taktik adalah bagian strategi untuk mencapai sasaran yaitu pengembangan eksistensi budaya. Pada level taktik, dipilih cara implementasinya agar faktor kebudayaan memiliki daya saing. Dalam pembangunan budaya, ketiganya penting karena sektor ini harus seimbang. Agar tujuan dan sasaran konservasi tercapai maka dalam redefinisi, revitalisasi dan reposisi strategi kebudayaan, stakeholders harus menjadi bagian dari pengambilan keputusan.

Rubin (Bryson dan Einsweiller 1988) mengembangkan strategi sektor publik berdasarkan waktu dan konteks terjadinya perubahan (Gambar 1-2). Strategi tersebut: pertama, "saga" (kronologi) yaitu pola tindakan jangka panjang untuk mengembalikan nilai dan tujuan yang mulai terancam hilang karena perubahan lingkungan, ketidak-tepatan atau kapasitas pengelolaan ke posisi semula. Idenya tidak mengembalikan masa lalu tetapi untuk memperoleh kembali kualitas yang hilang dan merespon situasi yang baru. Jenisnya: (a) restoratif mengembalikan kualitas yang hilang melalui kebijakan baru dan orientasi ulang; (b) reformatif, mengubah kebijakan dan prosedur pemerintah sehingga dapat merefleksikan apresiasi pada masa lalu; (c) rumah lindung (conservatory), tempat preservasi nilai, institusi dan tujuan yang terancam perubahan. Kedua, "Quests" (pertanyaan) yang menitik beratkan pada masa depan yang baru. Jenis strateginya (a) agenda baru tujuan dan sasaran jangka panjang; (b) visi besar terhadap kota, wilayah atau lembaga; (c) tindakan alternatif jangka panjang untuk mengantisipasi krisis atau konflik. 


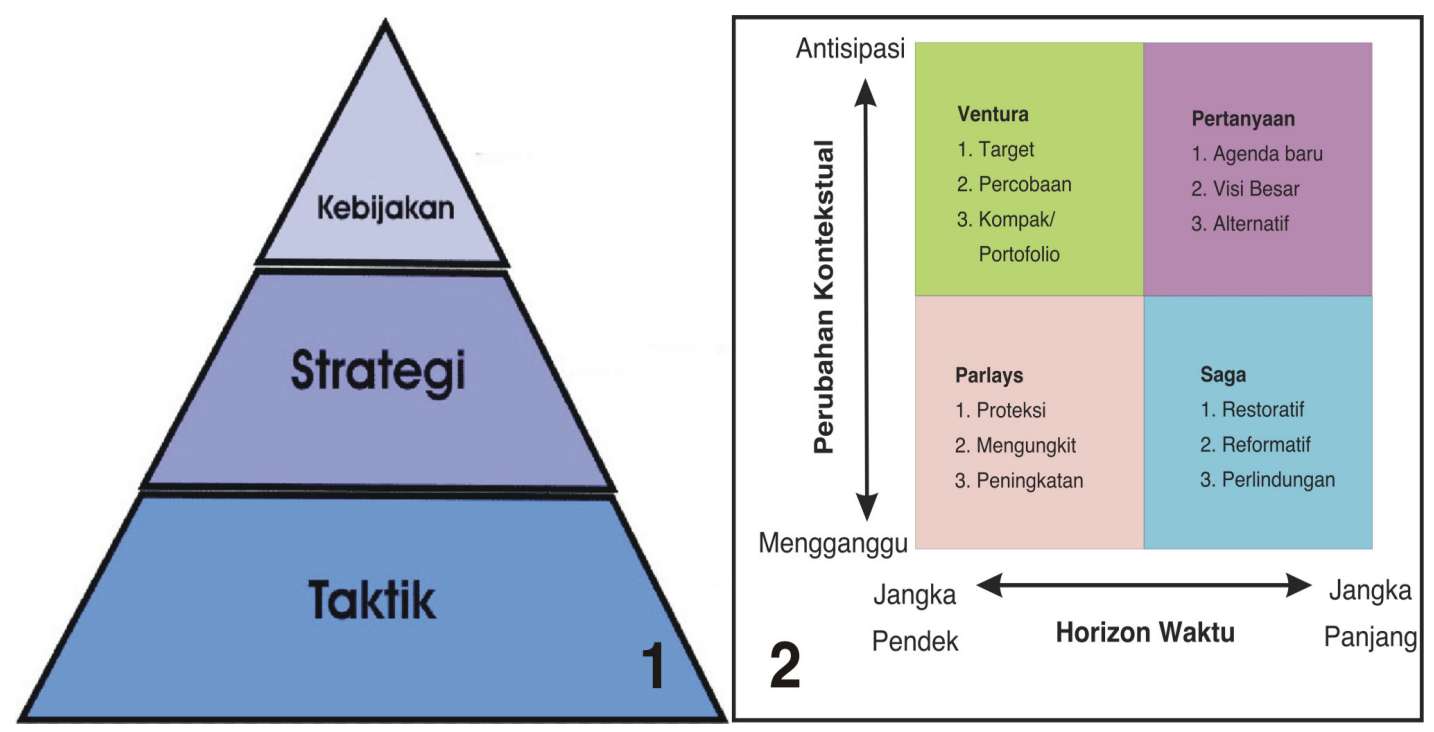

Sumber: Cappiello, et al. (1995: 5), Rubin (Bryson dan Einsweiller, 1988)

Gambar 1

Hirarki Keputusan dan Tipologi Keputusan Sektor Publik

Ketiga, ventura (venture) yang berasosiasi dengan (a) target keuntungan pada kesempatan yang relatif kecil; (b) percobaan (trial), eksperimen jangka pendek agar dapat bertransaksi dengan berbagai isu; (c) kompak (compact) atau perjanjian jangka pendek antar lembaga untuk melakukan aksi dan menanggung kesulitan bersama. Terakhir, "parlays", upaya memitigasi risiko yang tidak diinginkan dengan memberikan perlindungan jangka panjang. Tiga jenis strateginya adalah (a) proteksi (hedging) terhadap risiko; (b) mengungkit (leveraging atau engaging), upaya negosiasi memperoleh keunggulan; (c) peningkatan atau "advancing" - membuat respon jangka pendek pada situasi penting.

\section{Metode Penelitian}

Penelitian dilakukan dengan metode survei. Sampel diambil secara purposif pada 150 orang responden dari tokoh masyarakat, guru, aktivis lembaga swadaya masyarakat (LSM), muspida, pekerja seni dan anggota masyarakat lain yang dianggap dapat memberikan kontribusi pada penelitian ini. Berdasarkan formula Watson et al. (1993: 360) margin error ( $\alpha$ ) sampel 1,42 persen. Data primer dikumpulkan menggunakan wawancara dengan bantuan kuesioner terstruktur yang disampaikan kepada reponden yang berdomisili di Kota Yogyakarta yaitu meliputi daerah Kotagede Yogyakarta, Taman Sari, Kraton, atau menjadi pekerja di pusat seni tari ndalem Pujokusuman, museum dan sebagainya. Daerah ini dianggap cukup memiliki atraksi, amenitas dan aksesbilitas atau fasilitas yang dapat digunakan untuk menampilkan atribut kebudayaan. Adapun data sekunder digali dari berbagai literatur dan laporan, baik yang dipublikasikan atau tidak. Langkah penelitian terpampang pada Gambar 2. 


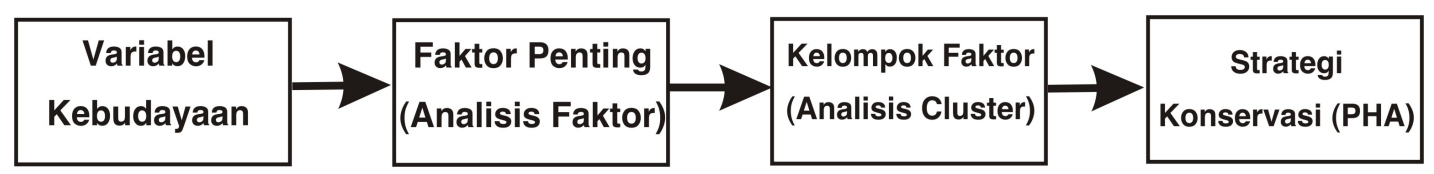

Gambar 2

Langkah Penelitian

Untuk mengetahui atribut kebudayaan penting yang terdapat pada masing-masing indikator digunakan analisis faktor dan analisis cluster (Hair, et al. 2006). Analisis faktor digunakan untuk membantu menentukan atribut-atribut atau faktor-faktor dalam setiap dimensi pemahaman masyarakat terhadap kebudayaan dengan mereduksi jumlah keseluruhan pernyataan menjadi beberapa faktor. Selanjutnya, faktor-faktor tersebut dikelompokkan berdasarkan urgensinya. Kemudian, strategi untuk menghadapi globalisasi ditetapkan dengan memakai teknik proses hirarki analitik (PHA) yaitu pengukuran prioritas berdasarkan pada skala rasio (Saaty 1986). PHA membantu menganalisis, mensistesiskan, mengevaluasi dan menjustifikasi pengambilan keputusan yang multi-kriteria dan kompleks. Di samping skala pengukuran, PHA menggunakan skala dasar atas peringkat relatif mulai dari 1 sampai dengan 9 (Kintarso dan Peniwati 2001). Melalui pendekatan ini, pembuat keputusan mengelaborasi pengetahuan pakar agar dihasilkan susunan informasi logis dalam hirarki.

\section{Hasil Penelitian dan Pembahasan}

Responden yang dijadikan penelitian mencakup 150 orang berumur antara 17-78 tahun dengan rerata 41,82 tahun yang terdiri dari tokoh masyarakat (27,3\%), guru (15,3\%), aktivis LSM (2\%), dan lain-lain termasuk muspida (55,3\%) dengan wanita mencapai 34,7 persen sedangkan pria 65,3 persen, yang berstatus menikah 76 persen dan tidak menikah 24 persen. Lama tinggal mereka di Yogyakarta berkisar 2-65 tahun dengan rerata 32,55 tahun.

Responden berpendidikan pascasarjana 13,3 persen, sarjana 51,3 persen, akademi 2,7 persen, SLTA 30,7 persen, SLTP 1,3 persen dan lainnya 0,7 persen. Sementara itu, pekerjaannya adalah PNS 70 persen, pensiunan 2,7 persen, swasta 6,7 persen dan lainnya 20,7 persen. Dari sampel tampak responden penelitian telah terdistribusi baik dengan mewakili penduduk di Yogyakarta dan mewakili berbagai strata sosial.

Dengan menggunakan sampel 150 orang, maka titik kritis factor loading yang dibutuhkan untuk menginterpretasi analisis faktor adalah sebesar 0,40 (Hair et al., 2006: 128). Dari pengolahan data tampak skor eigenvalues di atas 1 terletak pada tujuh faktor penting. Kemudian tujuh faktor penting dalam pelestarian kebudayaan di Yogyakarta yang terindikasi melalui pada Tabel 1 memberikan indikator: pertama, silaturahmi yang meliputi perlunya memelihara budaya saling berkunjung antar warga, menjaga suasana kekerabatan yang tetap kondusif, penyelesaian konflik dalam taraf kondusif melalui musyawarah, menciptakan kenyamanan kehidupan pergaulan di antara warga dan menjaga bahkan meningkatkan rasa percaya di antara anggota masyarakat. 
Tabel 1.

Faktor Wujud Kebudayaan

\begin{tabular}{|c|c|c|c|c|c|c|c|c|}
\hline \multirow{2}{*}{ Item } & \multicolumn{7}{|c|}{ Faktor } & \multirow{2}{*}{ Keterangan } \\
\hline & 1 & 2 & 3 & 4 & 5 & 6 & 7 & \\
\hline $\begin{array}{l}\text { Budaya saling berkunjung } \\
\text { antar warga }\end{array}$ & 0,78 & $(0,03)$ & 0,02 & 0,06 & 0,08 & 0,06 & 0,08 & \multirow[t]{5}{*}{ Silaturahmi } \\
\hline $\begin{array}{l}\text { Suasana kekerabatan } \\
\text { yang masih terjaga }\end{array}$ & 0,76 & 0,02 & 0,06 & 0,16 & 0,10 & 0,04 & 0,03 & \\
\hline $\begin{array}{l}\text { Musyawarah bagi } \\
\text { penyelesaian konflik }\end{array}$ & 0,63 & 0,10 & 0,24 & 0,13 & 0,12 & 0,07 & 0,15 & \\
\hline $\begin{array}{l}\text { Kenyamanan bergaul } \\
\text { antar warga }\end{array}$ & 0,50 & $(0,07)$ & 0,07 & 0,01 & $(0,02)$ & 0,11 & 0,44 & \\
\hline Kepercayaan antar warga & 0,50 & $(0,02)$ & 0,18 & $(0,17)$ & $(0,08)$ & 0,00 & 0,24 & \\
\hline $\begin{array}{l}\text { Kepercayaan terhadap } \\
\text { pendidikan, laku atau olah } \\
\text { bathin }\end{array}$ & 0,04 & 0,85 & 0,05 & 0,04 & $(0,00)$ & 0,04 & $(0,03)$ & \multirow[t]{3}{*}{ Spiritualisme } \\
\hline $\begin{array}{l}\text { Penggunaan petungan \& } \\
\text { pranatamangsa }\end{array}$ & $(0,03)$ & 0,77 & $(0,03)$ & 0,13 & 0,12 & 0,19 & $(0,03)$ & \\
\hline $\begin{array}{l}\text { Kepercayaan terhadap } \\
\text { supranatural }\end{array}$ & 0,02 & 0,73 & $(0,02)$ & $(0,15)$ & 0,10 & 0,04 & 0,11 & \\
\hline $\begin{array}{l}\text { Penghargaan pemerintah } \\
\text { terhadap karya seni }\end{array}$ & 0,40 & 0,08 & 0,70 & $(0,04)$ & 0,06 & 0,04 & $(0,01)$ & \multirow[t]{4}{*}{$\begin{array}{l}\text { Peran seluruh } \\
\text { elemen }\end{array}$} \\
\hline $\begin{array}{l}\text { Penghargaan masyarakat } \\
\text { terhadap karya seni }\end{array}$ & 0,54 & 0,06 & 0,57 & $(0,15)$ & $(0,02)$ & 0,11 & $(0,15)$ & \\
\hline $\begin{array}{l}\text { Keyakinan } \\
\text { mempertahankan } \\
\text { kebudayaan Jawa }\end{array}$ & 0,06 & 0,01 & 0,53 & 0,15 & 0,04 & 0,15 & 0,11 & \\
\hline $\begin{array}{l}\text { Kemudahan penerapan } \\
\text { Kromo Hinggil }\end{array}$ & 0,01 & $(0,07)$ & 0,43 & 0,14 & $(0,08)$ & 0,09 & 0,12 & \\
\hline $\begin{array}{l}\text { Tanggungjawab } \\
\text { pelestarian budaya Jawa }\end{array}$ & 0,18 & 0,08 & 0,00 & 0,76 & 0,05 & $(0,03)$ & $(0,02)$ & \multirow[t]{3}{*}{$\begin{array}{l}\text { Pengenalan } \\
\text { budaya dini }\end{array}$} \\
\hline $\begin{array}{l}\text { Pengenalan budaya Jawa } \\
\text { sejak dini }\end{array}$ & $(0,02)$ & 0,00 & 0,07 & 0,73 & $(0,06)$ & 0,13 & 0,01 & \\
\hline $\begin{array}{l}\text { Mendorong bahasa Jawa } \\
\text { bagi generasi muda }\end{array}$ & $(0,01)$ & $(0,09)$ & 0,25 & 0,43 & 0,15 & 0,07 & 0,02 & \\
\hline $\begin{array}{l}\text { Peran teknologi terhadap } \\
\text { degradasi budaya Jawa }\end{array}$ & 0,09 & 0,03 & 0,00 & 0,02 & 1,00 & $(0,01)$ & $(0,01)$ & \multirow[t]{2}{*}{$\begin{array}{l}\text { Mengimbangi } \\
\text { Kemajuan } \\
\text { teknologi }\end{array}$} \\
\hline $\begin{array}{l}\text { Peran teknologi terhadap } \\
\text { degradasi tata krama }\end{array}$ & 0,06 & 0,13 & 0,00 & 0,05 & 0,55 & 0,11 & 0,00 & \\
\hline $\begin{array}{l}\text { Pelaksanaan ritual budaya } \\
\text { Jawa }\end{array}$ & 0,15 & 0,13 & 0,13 & 0,06 & 0,09 & 0,95 & 0,15 & \multirow[t]{2}{*}{$\begin{array}{l}\text { Adat-istiadat } \\
\text { \& ritual Jawa }\end{array}$} \\
\hline $\begin{array}{l}\text { Penghormatan terhadap } \\
\text { leluhur }\end{array}$ & 0,06 & 0,14 & 0,24 & 0,11 & 0,06 & 0,56 & $(0,08)$ & \\
\hline Komunikasi antar warga & 0,30 & 0,10 & 0,16 & 0,01 & 0,02 & $(0,00)$ & 0,81 & \multirow[t]{2}{*}{ Komunikasi } \\
\hline Eigenvalues & 4,324 & 2,48 & 2,03 & 1,626 & 1,417 & 1,166 & 1,083 & \\
\hline
\end{tabular}

Sumber: Pengolahan Data (2007)

Kedua, spiritualisme, mendorong masyarakat untuk mengimbangi derasnya arus konsumerisme fisik pada era global melalui peningkatan pendidikan dan keimanan. Ketiga, perlunya peran seluruh elemen dan pemerintah membantu masyarakat melalui pemberian penghargaan karya seni, mendorong komunitas tetap yakin berpedoman pada kebudayaan Jawa sehingga dapat berperilaku sebagaimana orang Jawa (nJawani) dan 
mencari jalan bagaimana meningkatkan penggunaan bahasa Jawa terutama Kromo hinggil; Keempat, perlu intensitas pembelajaran dan pengenalan budaya Jawa sejak dini melalui pendidikan formal dan non-formal terutama dalam kaitannya dengan tanggungjawab untuk melestarikan budaya Jawa, dan mendorong penggunaan bahasa Jawa dalam keseharian, paling tidak dengan proporsi berimbang dengan Bahasa Indonesia pada acara yang tidak formal.Kelima, memberikan stimulan yang dapat mengimbangi kemajuan teknologi - misalnya menghidupkan kembali permainan (dolanan) pada anak seperti gobak sodor, bekelan, pasaran, jèk-jèk-an dan sebagainya yang relatif mendidik dan murah untuk mengimbangi play station atau computer game yang sarat introduksi budaya asing dan memerlukan uang yang relatif banyak. Cara lain yang mudah adalah memberi pemahaman peggunaan sesumber lokal bukan impor dari daerah lain misalnya mainan dari bahan glagah (bunga tebu), janur dan sebagainya. Kemudian faktor keenam adalah merevitalisasi adat-istiadat ritual kebudayaan Jawa seperti penghormatan kepada orang tua, pepundhèn dan leluhur. Penghormatan masyarakat kepada kultus orang tua pada dasarnya karena prioritas sifatnya yang kuasi religius masih tampak. Selaku tetua mereka dianggap lebih dekat dengan asal, sumber identitas dan kebijaksanaan, pada hidup, garis yang harus diteruskan dengan beranak-pinak dan membesarkannya sehingga disebut pepundhèn (yang diagungkan) oleh anak-anak (Mulder, 2001: 164). Hal ini tampak pada tradisi pulang kampung saat lebaran yang selalu dilakukan seorang anak meski dia telah berumah tangga untuk menghadap dan memohon berkah orang tua. Ketergantungan anak pada berkah orang tua dilanjutkan meskipun mereka sudah meninggal dunia dengan berziarah ke makamnya, mendoakan agar mereka mendapat tempat yang baik dan memohon diberikan ketenteraman hidup. Selain itu ritual masyarakat yang sering dilakukan adalah acara peringatan-peringatan terhadap sesuatu yang dianggap penting. Pada hari peringatan tersebut mereka mengadakan slametan (kenduri) yang bermakna selamat; upacara makan makanan bersama yang didahului doa tolak-bala oleh kyai atau kaum. Menurut Mulder (2001: 163) hal ini sebenarnya merupakan ekspresi keprihatinan dan harapan mereka bagi datangnya keselamatan yang lestari. Aktivitas sosial-budaya, tradisi dan ritual perlu dipertahankan sebagai identitas budaya. Perkampungan yang unik dapat berfungsi sebagai eko-resor lengkap dengan eko-budaya yang menghormati eksistensi pengetahuan tradisional, bahan baku serta keanekaragaman lokal. Daerah perkotaan yang khas seperti pecinan di Ketandan direvitalisasi, ditonjolkan rupa bentang-lahan beserta perangkat kehidupannya. Kemudian, menghidupkan kembali gotong-royong dan rembug warga sebagai media pengikat nilai-nilai yang menjadi ciri khas masyarakat.

Terakhir, menciptakan komunikasi yang sehat antar warga. Proses pembelajaran masyarakat bertumpu pada: (1) kompetensi: (a) pengetahuan; (b) ketrampilan - keahlian mengembangkan kapabilitas; (c) kemampuan mengerjakan sesuatu secara fisik, mental, finansial dan legal; (d) pengalaman kerja; (2) mendorong inovasi - dengan pelatihan dan kursus yang tidak membosankan; (3) motivasi - meningkatkan produktivitas, efisiensi, profitabilitas dan fleksibilitas dengan: (a) mengurangi hambatan semantik melalui peningkatan kemampuan berkomunikasi; (b) mengurangi hambatan teknis dengan merapikan sistem manajemen; (c) mengurangi hambatan manusiawi dengan mengawasi proses kegiatan; dan (d) mengurangi hambatan mekanis dengan cara mengubah proses sebagian atau seluruh sistem yang tidak efisien; dan (4) perluasan visi - melakukan pembandingan (benchmarking). 
Rescaled Distance Cluster Combine

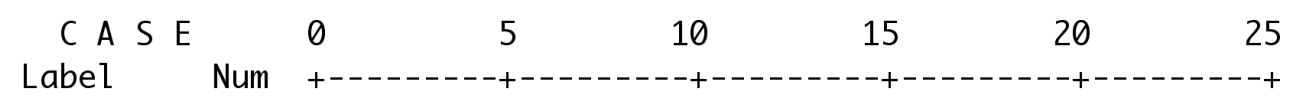

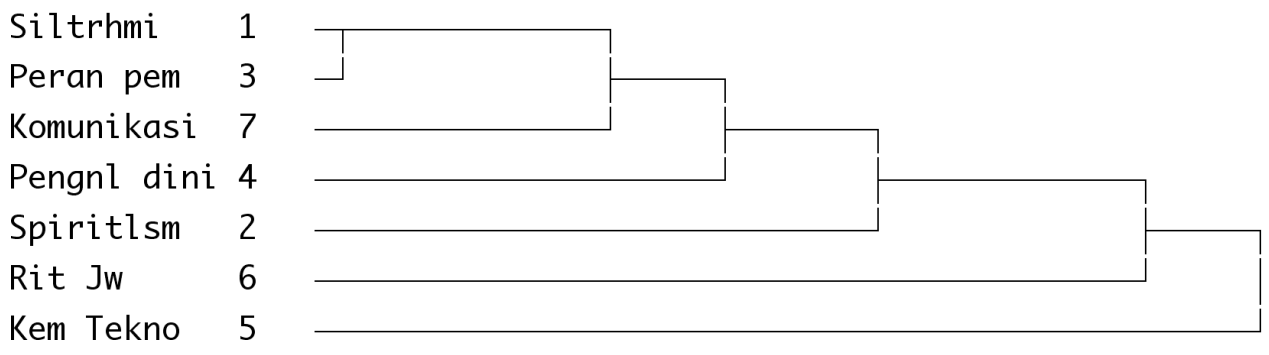

Sumber: Hasil Pengolahan Data (2007)

Gambar 3

Kelompok Faktor-faktor Penting dalam Pelestarian Wujud Kebudayaan

Kemudian dari analisis kelompok (cluster) terhadap faktor-faktor tersebut diperoleh dua kelompok besar. Pada Gambar 3 terlihat bahwa dalam pelestarian kebudayaan faktor silaturahmi, peranan pemerintah, komunikasi antar warga, pengenalan budaya sejak dini, spiritualisme, adat-istiadat dan ritual Jawa bergabung menjadi satu kelompok yang disebut "edukasi", sedangkan stimulator untuk mengimbangi "kemajuan teknologi" berdiri mandiri. Pada Tabel 2 diperlihatkan fisik kebudayaan yang harus diperhatikan yaitu: pertama, menyampaikan nilai-nilai yang terkandung di dalam kesenian kepada masyarakat. Kedua, menciptakan suasana progresivitas olah seni sehingga terkesan tidak membosankan, mengingat seni budaya lokal akan berhadap-hadapan secara frontal dengan budaya asing misalnya play station. Ketiga, perlu dilakukan modifikasi performace seni pertunjukan (bukan pakemnya), misal: kostum, cara penyelenggaraan dan cara memberikan pelajaran.

Keempat, pelestarian heritage, misalnya wayang kulit yang telah ditetapkan sebagai pusaka dunia (world heritage), macapat dan kethoprak dengan memberikan ruang untuk tampil dan memasukkannya sebagai muatan lokal pada kurikulum pendidikan yang dimulai sejak sekolah dasar. Kelima, mempertahankan penggunaan busana dengan motif batik dan lurik. Misalnya dengan mewajibkan pegawai instansi di Yogyakarta baik negeri maupun swasta untuk menggunakan busana bermotif batik pada hari Senin dan menggunakan busana tradisional Jawa lengkap peranakan (baju lurik) pada hari Jumat. Hal ini kecuali mendorong orang untuk bangga terhadap motif lokal juga akan meningkatkan perekonomian masyarakat khususnya pengrajian yang menanganinya. Keenam, menjaga budaya kedisiplinan, ketertiban dan keteraturan; misalnya membuang sampah. Kecuali itu, tata krama, unggah-ungguh yang lekat dengan budaya Jawa mulai disosialisasikan kembali baik melalui institusi formal seperti sekolah maupun non-formal (keluarga) dan ditanamkan sejak dini. Ketujuh, pelestarian seni tari dan kerawitan dimulai dari institusi pemerintah dengan mewajibkan anggota unit untuk mempelajarinya. Pada acara tertentu diadakan pertandingan antar unit plus kelompok masyarakat yang ingin bergabung. 
Tabel 2

Faktor Fisik Kebudayaan

\begin{tabular}{|c|c|c|c|c|c|c|c|c|}
\hline \multirow{2}{*}{ Item } & \multicolumn{7}{|c|}{ Faktor } & \multirow{2}{*}{ Keterangan } \\
\hline & 1 & 2 & 3 & 4 & 5 & 6 & 7 & \\
\hline Nilai tarian & 0,85 & 0,12 & 0,05 & $(0,08)$ & 0,04 & 0,04 & 0,22 & \multirow[t]{6}{*}{$\begin{array}{l}\text { Nilai } \\
\text { kesenian }\end{array}$} \\
\hline Nilai kerawitan & 0,77 & 0,18 & $(0,02)$ & $(0,00)$ & 0,14 & 0,03 & 0,12 & \\
\hline Nilai wayang orang & 0,73 & 0,10 & 0,02 & 0,27 & 0,07 & 0,05 & 0,03 & \\
\hline Nilai kethoprak & 0,72 & 0,16 & $(0,00)$ & 0,24 & 0,02 & 0,05 & $(0,05)$ & \\
\hline Nilai tembang & 0,70 & 0,10 & 0,01 & 0,10 & 0,21 & 0,05 & $(0,03)$ & \\
\hline $\begin{array}{l}\text { Kraton sebagai pusat } \\
\text { budaya masyarakat }\end{array}$ & 0,24 & 0,21 & $(0,09)$ & 0,21 & $(0,00)$ & 0,20 & 0,13 & \\
\hline Seni kerawitan up to date & 0,07 & 0,86 & 0,06 & 0,09 & 0,02 & $(0,00)$ & $(0,02)$ & \multirow[t]{6}{*}{ Progresivitas } \\
\hline Tarian up to date & 0,15 & 0,75 & $(0,07)$ & $(0,04)$ & 0,08 & 0,09 & 0,19 & \\
\hline Mancapat up to date & 0,15 & 0,73 & 0,02 & 0,17 & 0,08 & $(0,01)$ & 0,02 & \\
\hline $\begin{array}{l}\text { Wayang orang up to } \\
\text { date }\end{array}$ & 0,10 & 0,63 & 0,04 & 0,35 & $(0,04)$ & 0,03 & 0,02 & \\
\hline Kethoprak up to date & 0,19 & 0,55 & 0,08 & 0,32 & 0,01 & 0,04 & $(0,09)$ & \\
\hline $\begin{array}{l}\text { Perasaan nyaman } \\
\text { menggunakan kebaya \& } \\
\text { surjan }\end{array}$ & 0,17 & 0,24 & $(0,11)$ & 0,17 & 0,16 & 0,07 & 0,13 & \\
\hline Modifikasi seni kerawitan & $(0,02)$ & 0,02 & 0,80 & $(0,05)$ & 0,05 & $(0,00)$ & 0,07 & \multirow[t]{5}{*}{$\begin{array}{l}\text { Modifikasi } \\
\text { penampilan }\end{array}$} \\
\hline Modifikasi mancapat & 0,02 & 0,00 & 0,80 & $(0,03)$ & $(0,05)$ & $(0,15)$ & $(0,15)$ & \\
\hline Modifikasi tarian & 0,11 & $(0,06)$ & 0,68 & $(0,15)$ & $(0,02)$ & $(0,02)$ & $(0,15)$ & \\
\hline Modifikasi wayang orang & 0,01 & 0,05 & 0,60 & $(0,19)$ & 0,03 & $(0,02)$ & $(0,00)$ & \\
\hline Modifikasi kethoprak & $(0,10)$ & 0,02 & 0,54 & $(0,12)$ & 0,07 & 0,15 & $(0,02)$ & \\
\hline Pelestarian wayang & 0,11 & 0,27 & $(0,27)$ & 0,76 & 0,06 & $(0,02)$ & 0,14 & \multirow[t]{3}{*}{$\begin{array}{l}\text { Pelestarian } \\
\text { heritage }\end{array}$} \\
\hline Pelestarian kethoprak & 0,18 & 0,23 & $(0,26)$ & 0,69 & 0,02 & 0,05 & 0,14 & \\
\hline Pelestarian mancapat & 0,14 & 0,28 & $(0,27)$ & 0,54 & 0,07 & 0,04 & 0,20 & \\
\hline $\begin{array}{l}\text { Keagungan tampilan } \\
\text { motif batik \& lurik }\end{array}$ & 0,09 & 0,09 & $(0,02)$ & 0,01 & 0,86 & 0,05 & 0,13 & \multirow[t]{4}{*}{$\begin{array}{l}\text { Mempertah } \\
\text { ankan motif } \\
\text { batik \& lurik }\end{array}$} \\
\hline $\begin{array}{l}\text { Kebanggaan } \\
\text { menggunakan motif batik } \\
\& \text { lurik }\end{array}$ & 0,07 & 0,01 & 0,03 & 0,02 & 0,85 & 0,02 & 0,01 & \\
\hline $\begin{array}{l}\text { Morif batik \& lurik up to } \\
\text { date }\end{array}$ & 0,12 & $(0,06)$ & 0,23 & 0,03 & 0,48 & 0,18 & $(0,04)$ & \\
\hline $\begin{array}{l}\text { Kebanggaan berkebaya } \\
\& \text { bersurjan }\end{array}$ & 0,17 & 0,20 & $(0,11)$ & 0,05 & 0,29 & $(0,03)$ & 0,07 & \\
\hline $\begin{array}{l}\text { Menjaga ketertiban dan } \\
\text { keteraturan }\end{array}$ & 0,06 & 0,03 & 0,01 & 0,01 & 0,04 & 0,95 & $(0,00)$ & \multirow[t]{2}{*}{$\begin{array}{l}\text { Menjaga } \\
\text { kedisiplinan, } \\
\text { Ketertiban }\end{array}$} \\
\hline Menjaga keasrian & 0,10 & 0,07 & $(0,03)$ & 0,04 & 0,14 & 0,87 & 0,02 & \\
\hline Pelestarian tarian gaya YK & 0,18 & 0,04 & $(0,14)$ & 0,41 & 0,17 & 0,03 & 0,86 & \multirow[t]{2}{*}{$\begin{array}{l}\text { Pelestarian } \\
\text { seni tari \& } \\
\text { kerawitan }\end{array}$} \\
\hline Pelestarian kerawitan & 0,22 & 0,19 & $(0,24)$ & 0,48 & 0,04 & $(0,04)$ & 0,49 & \\
\hline
\end{tabular}

Sumber: Hasil Pengolahan Data (2007) 
Berikutnya berdasarkan analisis kelompok (cluster) terhadap faktor-faktor tersebut diperoleh dua kelompok besar. Pada Gambar 4 terlihat bahwa dalam pelestarian fisik kebudayaan faktor progresivitas olah seni, pelestarian heritage, nilai kesenian, mempertahankan motif batik dan lurik, modifikasi seni pertunjukan, pelestarian seni tari dan kerawitan, bergabung menjadi satu kelompok yang disebut "seni", sedangkan faktor disiplin, ketertiban dan keteraturan berdiri mandiri.

\section{Rescaled Distance Cluster Combine}

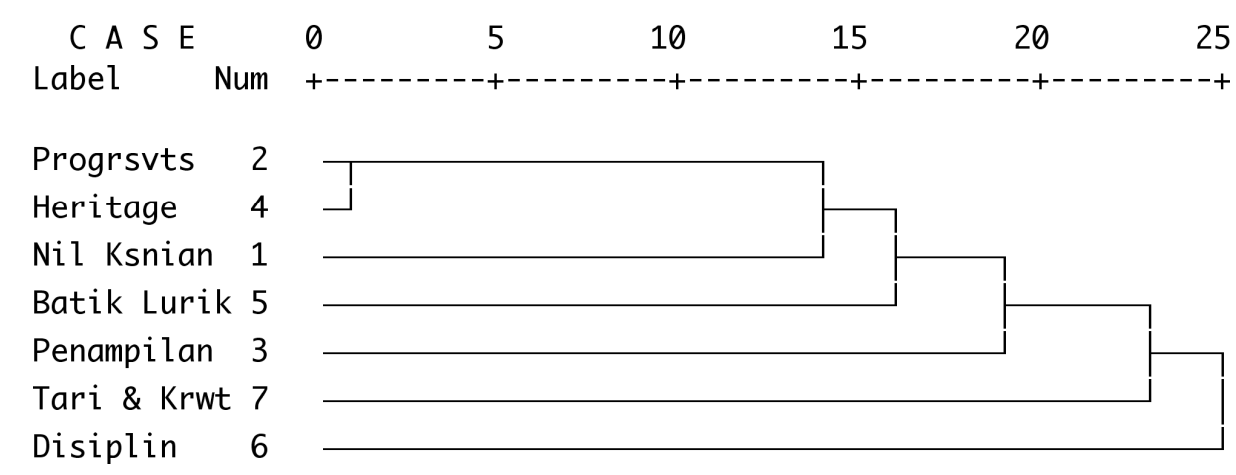

Sumber: Hasil Pengolahan Data (2007)

Gambar 4

Kelompok Faktor-Faktor Penting dalam Pelestarian Fisik Kebudayaan

Pada dasarnya di dalam pariwisata unsur atraksi, aksesbilitas dan amenitas tidak boleh dilupakan. Unsur atraksi dilakukan dengan menghidupkan kembali permainan (dolanan) tradisional, wisata tematik seperti wisata religi, kuliner dan lain-lain. Aksesbilitas dipenuhi melalui penyediaan tempat informasi yang representatif dan ditangani oleh orang profesional berbasis pada keramah-tamahan (hospitality). Di samping itu dipakai peralatan pemasaran dan pencitraan yang teritegrasi dan simultan. Adapun amenitas, yang mencerminkan keramah-tamahan Kota dan warga Yogyakarta sebagai tanda mata pengingat wisatawan untuk melakukan pembelian ulang adalah dengan menciptakan karya seni yang dapat menginterpretasikan budaya lokal. Bahan bakunya sedapat mungkin mencari sumberdaya yang ada di sekitar Yogyakarta pula. Dua kebijakan utama dalam menghadapi globalisasi yang perlu diperhatikan adalah edukasi dan mengimbangi invasi teknologi barat. Hal ini perlu dilakukan karena isu pariwisata tidaklah dapat lepas dari industri kebudayaan yang berkembang pesat dewasa ini. Bila tidak dilakukan penetrasi terhadap pendidikan sejak usia dini maka dikelak kemudian hari kebudayaan Jawa akan menjadi tinggal kenangan. Nilai-nilai kebudayaan seperti estetika dan harmoni, spiritual, sosial, sejarah, simbolis, dan keaslian perlu dipertahankan.

Melalui Tabel 3 kebijakan edukasi melibatkan, pertama, strategi pemahaman terhadap aspek kognitif (cognitive) berupa penalaran dan pemahaman dikombinasikan dengan aspek afektif (affective) yang berkaitan dengan cita rasa tentang arti pentingnya pelestarian pusaka (heritage) dengan memberikan introduksi kepada masyarakat untuk memiliki rasa handarbeni kebudayaan, sehingga perlu diberikan sejak usia dini. Para siswa tidak hanya 
diberikan cara menghapal (misalnya anak cicak bernama sawiyah, atau daun ketela namanya jlégor) tetapi juga bentuk implementasinya. Strategi ini diterapkan melalui pendidikan formal (sekolah) dan non-formal melalui keluarga, kelompok bermain dan lainlain. Setelah itu dilakukan sosialisasi berkesinambungan dengan penekanan pada perbaikan terus menerus (continues improvement) untuk merevitalisasi adat-istiadat terutama yang mulai dilupakan orang. Adat-istiadat termasuk praktik kehidupan keseharian masyarakat merupakan obyek wisata budaya yang tidak habis dimakan zaman. Keanekaragaman budaya (cultural diversity) selalu menarik wisatawan untuk dilihat karena menjadi ukuran variasi kehidupan manusia sehingga merefleksikan hubungan antara manusia dan lingkungan alamnya. Alam, dalam konteks ini, adalah rekan pendamping bagi manusia.

Kedua, mengembangkan ketrampilan (soft skill) dengan fokus pada aspek konatif (conative) yang berhubungan dengan daya cipta dan karsa manusia. Imlementasi strategi ini dapat melalui sekolah dengan menggalakkan prakarya seperti tenun, anyaman bambu atau jalur koperasi, kelompok sadar wisata, kelompok usaha dan sebagainya. Kemudian dapat pula diadakan bengkel kerja (workshop) di setiap kecamatan atau kelurahan yang dapat mengajarkan ketrampilan praktis menunjang ekonomi keluarga, misalnya merangkai bunga, beternak burung dan sebagainya. Agar tidak jenuh, setiap periode tertentu perlu diadakan lomba dengan insentif yang merangsang minat untuk berkarya. Kebijakan berikut adalah upaya mengimbangi teknologi barat yang merasuk pada segala aspek kehidupan terutama pariwisata. Strateginya, pertama, adalah menghidupkan kembali permainan anak dan penggunaan sesumber bahan baku lokal. Taktik yang dilakukan adalah melakukan perencanaan kegiatan sosial-budaya secara tepat dengan menempatkan guru kebudayaan seperti seni tari, musik, kerawitan selain ke sekolah-sekolah juga ke ranah masyarakat seperti kelurahan bahkan kampung-kampung dengan koordinasi pemimpin wilayah yang formal (camat, lurah, ketua RW atau ketua RT) atau tokoh masyarakat. Di samping itu, perlu didukung pula oleh ahli manajemen untuk membantu mengorganisasi seni pertunjukan.

Ketiga, melakukan perlindungan budaya secara terintegrasi melalui pengayaan keanekaragaman wisata budaya berbasis komunitas (misalnya wisata spritual dan religi, wisata kuliner lokal dan lain-lain) serta pelestarian benda cagar budaya yang menjadi identitas dan landmark kota Yogyakarta. Kemudian memberikan penghargaan kepada khalayak ramai yang memberikan kontribusi pada dunia seni-budaya setiap periode tertentu. Namun juga menindak tegas bahkan mencari ke akar-akarnya pelaku graffiti yang mengganggu keasrian dan keindahan.

Keempat, memberdayakan komunikasi dan melakukan pencitraan terhadap Kota Yogyakarta secara optimal melalui teknik pemasaran yang terintegrasi (misalnya leaflet, baliho, ekspo, brosur, e-tourism, dan yang terpenting karena sifatnya yang efektif dan efisien adalah word of mouth - pemasaran melalui mulut ke mulut) dan penyediaan pusat informasi pariwisata yang up to date didukung sumberdaya yang memadai dan representatif. Tenaga kerja pada pusat informasi sebaiknya ditunjuk dari person, bukan karena tingkat eselon atau jabatannya akan tetapi memang murni pada profesionalitasnya. Keempat, menjaga pelestarian dengan berbasis masyarakat local yaitu menjaga nilai pranata sosial, tata-krama, unggah-ungguh dan kedisiplinan serta keteraturan. Hal ini dapat dimulai dengan penataan PKL malioboro, juru parkir yang terkesan semrawut dan anarkis (dengan menafikan kaum pedestrian). Selanjutnya, tentu melalui institusi formal, diajarkan kepada siswa sejak usia dini bagaimana perlunya memberikan respek kepada orang yang dituakan dan sebagainya. 
Tabel 3

Kebijakan, Strategi dan Implementasi

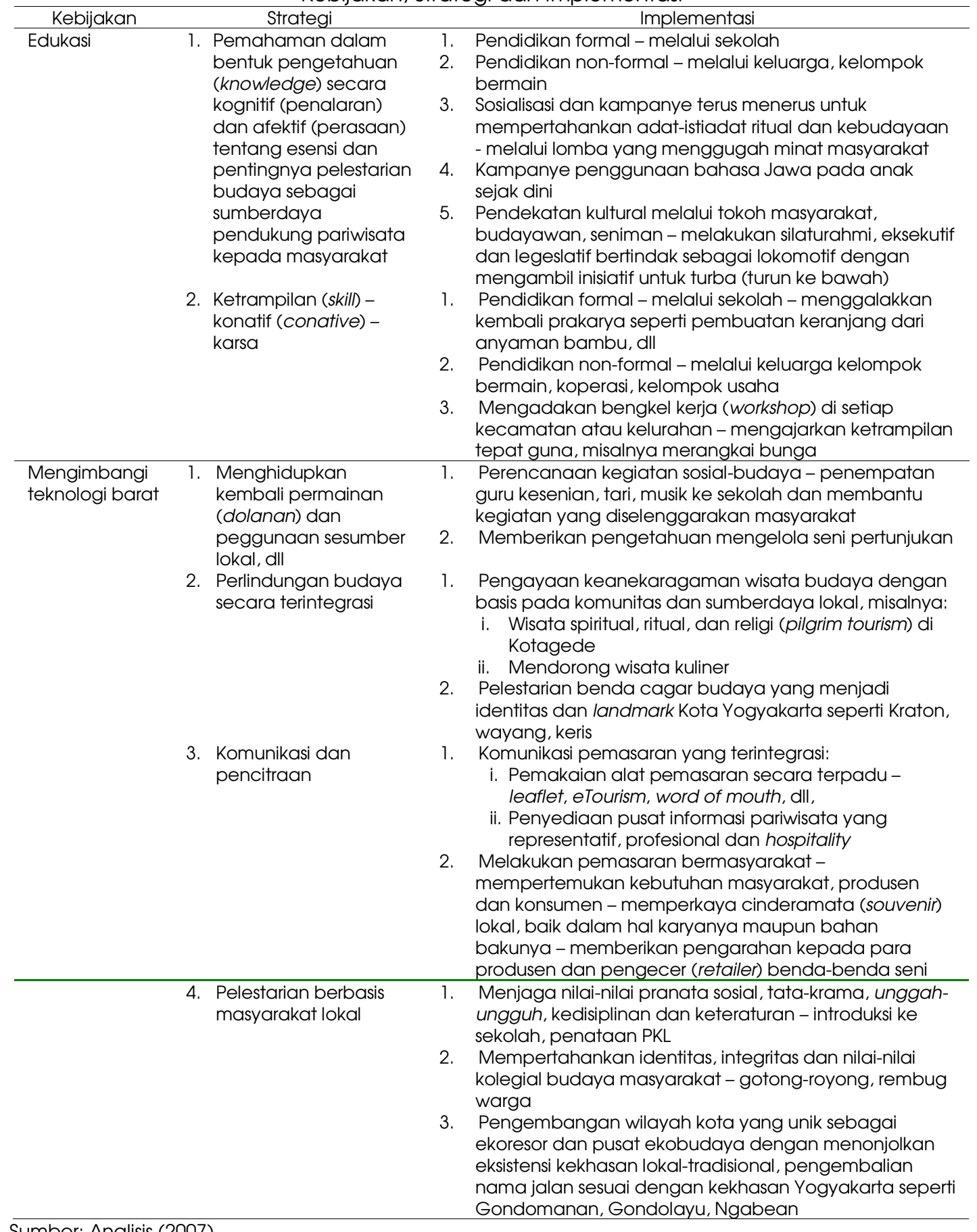


Hal lain yang perlu diperhatikan adalah menjaga identitas, integritas dan nilai budaya masyarakat seperti gotong-royong, rembug rembug warga, pengembangan wilayah kota yang unik seperti kampung dan pecinan sebagai ekoresor (penginapan yang ramah lingkungan) dan daerah ekobudaya dengan menonjolkan eksistensi kekhasan lokaltradisional. Misalnya karena pecinan merupakan wilayah khas etnis cina, maka pertunjukan barongsai menjadi unggulan, sedangkan kampung yang menjadi kosa kata bahasa Inggris kampoong adalah daerah unik karena secara faktual ada di daerah urban tetapi cara hidup warganya masih semi perdesaan. Kehidupan yang dualistik ini sangat menarik untuk dikembangkan menjadi obyek dan daya tarik wisata. Selain itu penamaan kembali jalanjalan yang khas Yogyakarta yang tidak ada ditempat lain, karena dulunya dikaitkan dengan rumah kepangeranan atau institusi kraton, misalnya Ngabean, Gondomanan, Loji Kecil, Gerjen, Yudonegaran, Pangurakan dan lain-lain.

Berdasarkan Tabel 3, prioritas kebijakan, strategi dan implementasi konservasi sumberdaya kebudayaan lokal Yogyakarta disusun dengan menggunakan teknik AHP (penggaliannya menggunakan metode Delphi dengan mengeksplorasi pendapat pakar). Selanjutnya melalui Gambar 5 dan Gambar 6-1, tampak prioritas kebijakan konservasi kebudayaan lokal Yogyakarta adalah melalui jalur edukasi $(83,3 \%$ ) dan upaya mengimbangi teknologi barat $(16,7 \%)$ dengan menghidupkan kembali permainan anak dan penggunaan sesumber bahan baku lokal, perlindungan kebudayaan secara terintegrasi, komunikasi dan pencitraan kebudayaan Yogyakarta dan pelestarian berbasis masyarakat.

Adapun implementasi untuk mencapai tujuan adalah melalui pendidikan formal sekolah (29\%), kemudian melalui agen pendidikan non formal $(25,6 \%)$ seperti keluarga, kelompok bermain dan sebagainya. Cara lain adalah sosialisasi (14,2\%) dan pendekatan kultural melalui tokoh masyarakat (11,7\%) yang diikuti oleh penerjunan guru atau pakar seni-budaya $(3,5 \%)$ ke berbagai sekolah dan wilayah masyarakat. Langkah lebih lanjut adalah menciptakan bengkel kerja di kecamatan (2,8\%), pengayaan aneka wisata $(2,1 \%)$ dan perlindungan terhadap benda cagar budaya $(2,1 \%)$ baik yang berwujud (tangible) maupun yang tidak berwujud (intangible). Jika konstelasi ini diubah, misalnya peluang kebijakan edukasi dan spirit untuk bertindak mengimbangi teknologi barat adalah sama besar (50\%), maka nampaknya pendidikan formal masih merupakan cara terbaik untuk mencapai tujuan yang telah ditetapkan yaitu konservasi kebudayaan lokal Yogyakarta dalam menghadapi globalisasi pariwisata (Gambar 6-2).

Mengacu kepada Rubin (Bryson dan Einsweiller 1988), secara keseluruhan strategi yang diterapkan mempunyai dimensi jangka panjang dengan tujuan untuk mengantisipasi atau memperbaiki perubahan konteks dalam hal ini kebudayaan di Yogyakarta. Secara umum strateginya dalam sel "quest" atau pertanyaan dan "saga" (Gambar 1-2). Dengan demikian langkah yang dilakukan bersifat: (1) restoratif untuk mengembalikan "kebersamaan" masyarakat yang hilang melalui kebijakan dan agenda orientasi institusional yang baru; (2) reformatif, merubah kebijakan dan prosedur pemerintah dengan melakukan apresiasi terhadap sesumber lokal; sekaligus (3) perlindungan terhadap nilai, norma atau hakekat kebudayaan Jawa yang terancam oleh perubahan lingkungan. 


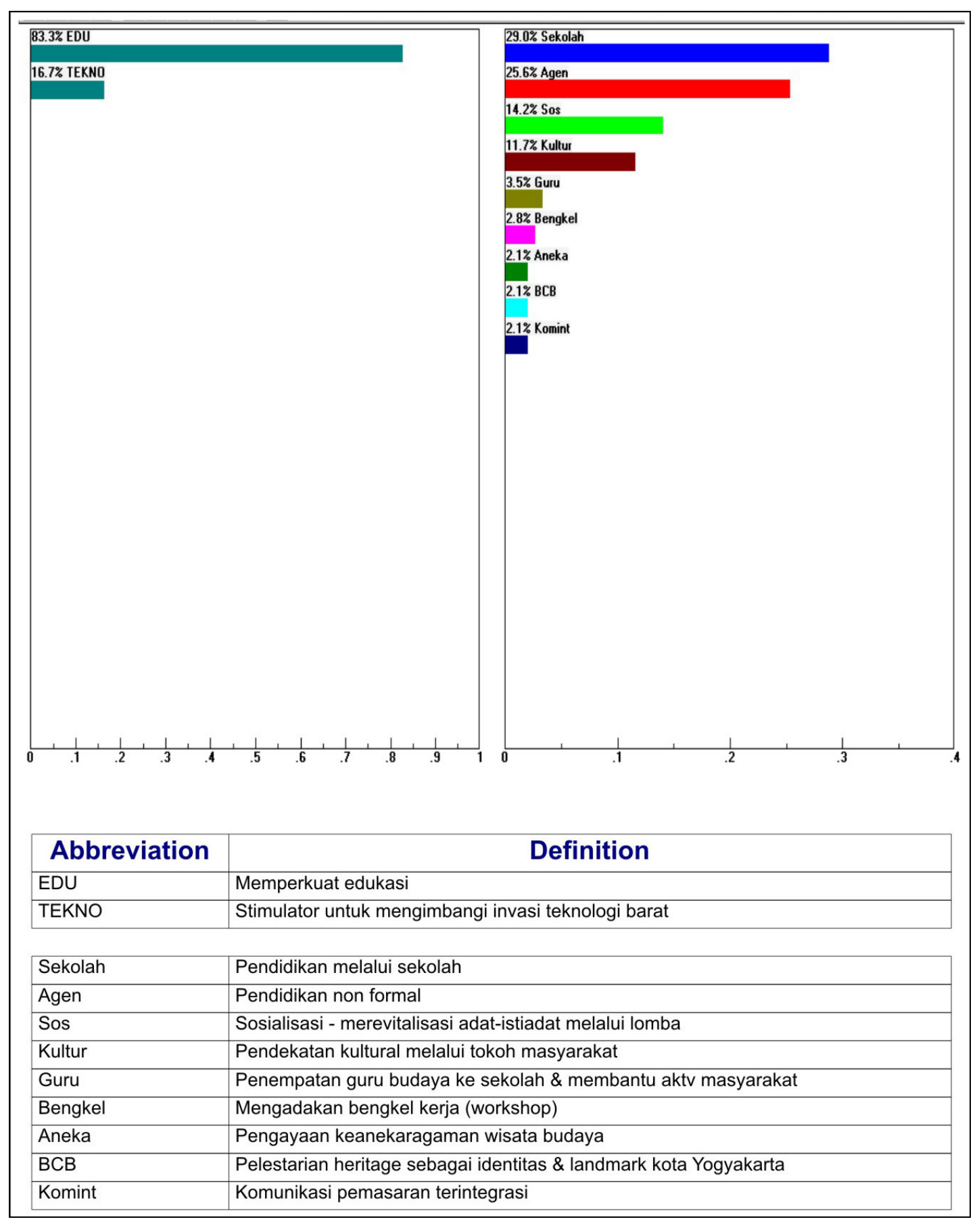

Gambar 5

Prioritas Kebijakan Pelestarian Kebudayaan Lokal Yogyakarta 


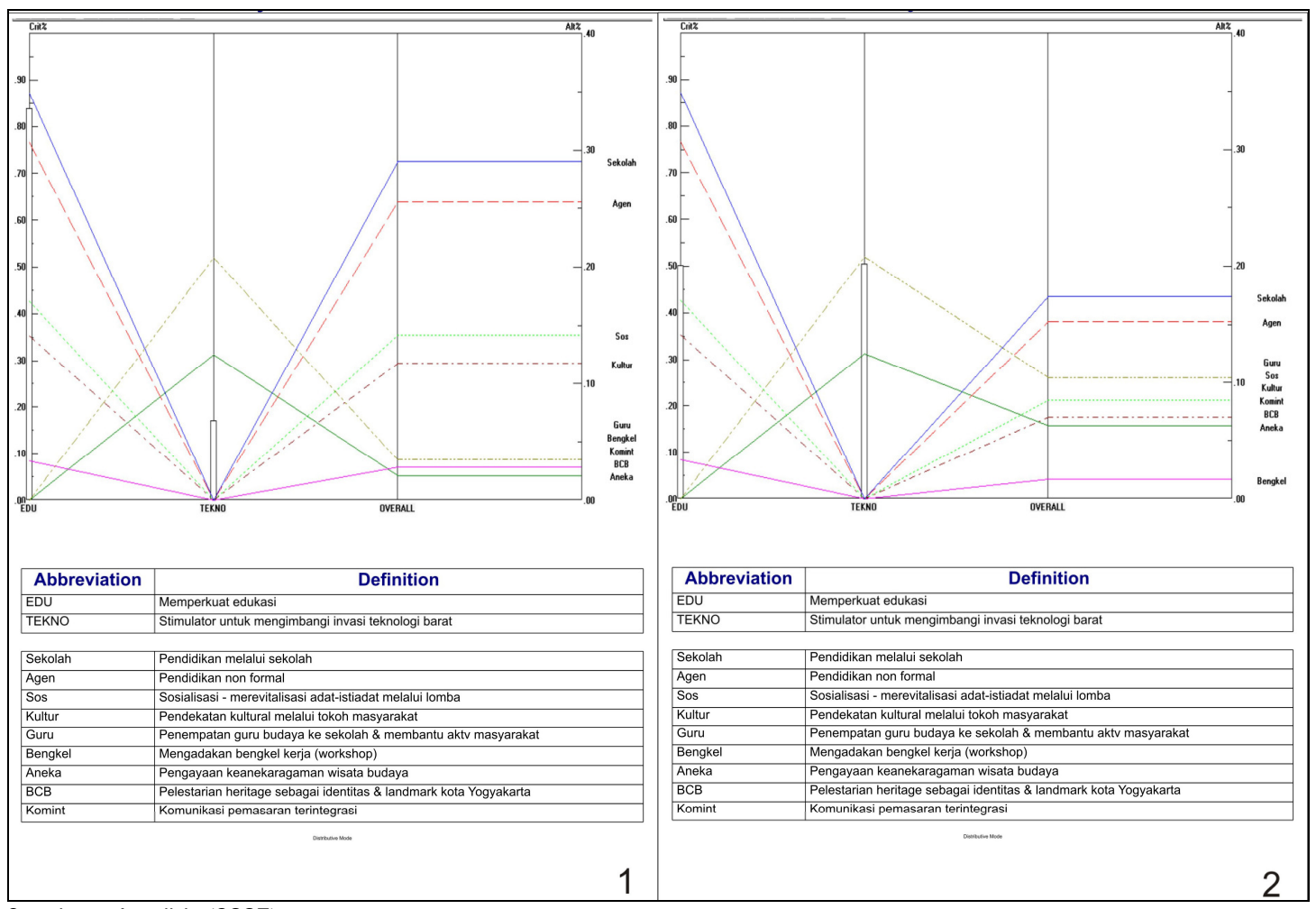

Sumber: Analisis (2007)

\section{Gambar 6}

Analisis Sensitivitas Perubahan Kebijakan Pelestarian Kebudayaan

Kemudian, sebagai langkah antisipasi terhadap semakin menurunnya fungsi kebudayaan Jawa di masyarakat perlu (1) sebuah agenda baru dengan tujuan dan sasaran jangka panjang berupa masyarakat yang maju, mandiri, sejahtera lahir batin yang didukung oleh nilai-nilai kejuangan dan pemerintahan yang baik dan bersih dengan mengembangkan ketahanan sosial-budaya dan sumberdaya berkelanjutan; (2) penerapan visi besar terwujudnya pembangunan regional, wahana menuju kondisi Yogyakarta pada tahun 2020 sebagai pusat pendidikan, kebudayaan, dan daerah tujuan wisata budaya terkemuka.

\section{Simpulan}

Simpulan dari riset ini, pertama, faktor-faktor penting dalam konservasi kebudayaan lokal adalah (1) dalam hal faktor wujud kebudayaan, perlu menjaga silaturahmi antar warga (untuk menciptakan suasana kondusif), mengedepankan spiritualisme dalam bentuk pendidikan dan keimanan, melibatkan peran seluruh elemen masyarakat untuk menghargai seni-budaya, melakukan pengenalan budaya Jawa sejak dini sekaligus menggalakkan penggunaan bahasa Jawa pada acara non formal, mencari stimulan yang dapat mengimbangi kemajuan teknologi dengan merevitalisasi adat-istiadat ritual kebudayaan Jawa, serta melakukan komunikasi yang sehat antar sesama warga; (2) dalam hal fisik 
kebudayaan perlu digali kembali nilai-nilai yang terkandung di dalam kesenian masyarakat, menjaga progresivitas di dalam melakukan olah seni, memodifikasi cara penyelenggaraan dan pembelajaran seni pertunjukan, pelestarian heritage, mempertahankan penggunaan busana dengan motif batik dan lurik, menjaga kedisiplinan, ketertiban, keteraturan dan tatakrama, serta pelestarian seni tari tradisional dan kerawitan. Kedua, perlu penerapan dua kebijakan penting yaitu edukasi baik kognitif, afektif dan konatif serta mencari stimulan yang dapat menangkal invasi teknologi barat.

Implikasi temuan penelitian ini adalah: (1) untuk menghadapi derasnya arus globalisasi budaya, Kota Yogyakarta harus dapat menampilkan keunikan yang dapat menunjang upaya "glokalisasi". Hal ini dapat tercapai jika seluruh elemen masyarakat tampil. Namun untuk itu peran eksekutif dan legislatif sebagai representasi masyarakat diperlukan sebagai motor penggerak; (2) pendataan kuantitas dan kualitas guru kesenian untuk diterjunkan ke sekolah-sekolah membantu merevitalisasi budaya Jawa yang sudah mulai meredup nilai dan esensinya. Jangan sampai di kelak kemudian hari bila anak cucu ingin mengetahui kebudayaan Jawa harus harus pergi jauh belajar ke negeri orang.

\section{Daftar Referensi}

Ayala, H. 1996. Resort ecoturism: A Paradigm for the $21^{\text {st }}$ century. Cornell Hotel and Restaurant Administration Quarterly, 37 (5): 46-53.

Brown, L.R. 2001. Eco-Economy: Building an Economy for the Earth. New York: W.W. Norton \& Company.

Bryson, J.M. and R.C. Einsweiller. 1988. Strategic Planning: Threats and Oppourtinities for Planners. Chicago: Planners Press.

Cappiello, S., M. Freed., M. Jacobsen., and J. Taylor. 1995. A Product Launch Strategy for Kid Science. Paper presented in EES 283, June 9, 1995.

Ekonomi Kreatif, 2007. Ekonomi Kreatif di Indonesia. ekonomikreatif.blogspot.com

Featherstone, M. 1990. Global Culture. London: Sage Publication Ltd.

Ferguson, G. and K. Scadden. 2004. Waitaker City Heritage Strategy. Report is prepared for Waitaker City Council.

Goeldner, C.R. and J.R.B. Ritchie. 2003. Tourism: Principles, Practices, Philosophies. (9th ed.). New York: John Wiley \& Sons.

Gossen, C. 1993. Ecoculture and Survival: Sustainability vs. Habit \& Behavior Sustainable Structures. Unpublished document. Portland, Oregon.

Hair, J.F., Jr., W.C. Black, B.J. Babin, R.E. Anderson., and R.L. Tatham. 2006. Multivariate Data Analysis. (5 $5^{\text {th }}$ ed.). Upper Saddle River, NJ, USA: Pearson Education, Inc.

Haley, D. 2001. Creative interventions: Ecoculture and aesthetics diversity. Common Places Workshop in Public Art Observatory, Oporto.

Kintarso, H., dan K. Peniwati. 2001. Menentukan strategi bisnis serta memprioritaskan kegiatan rencana strategis pada perusahaan baja perkakas dengan menggunakan "analytic hierarchy process". Konferensi Akademi Manajemen Indonesia. Jakarta 29 Oktober-1 November 2001.

Koentjaraningrat. 2004. Bunga Rampai Kebudayaan, Mentalitas, dan Pembangunan. Jakarta : PT Gramedia Pustaka Utama.

Langabeer II, J. 1998. Competitive strategy in turbulent healthcare markets: An analysis of financially effective teaching hospitals. Journal of Healthcare Management, 43 (6): 512526. 
Lee, D.N.B. and D.J. Snepenger. 1992. An ecotourism assessment of Tortuguero, Costa Rica. Annals of Tourism Research, 19 (2): 1367-1370.

Merric, H.J. and J. Hunt. 1998. Ecotourist' motivational and demographic characteristics: A case of North Carolina travelers. Journal of Travel Research, 36 (Spring): 57-61.

Mintohardjo, H.S. 2007. Tantangan Global Pengembangan Ilmu Pengetahuan, Teknologi, dan Seni (IPTEKS): Tinjauan dari Perspektif Kultural. Makalah Pelatihan Peningkatan Wawasan Dosen Tentang Fondasi Etika dan Estetika dalam Pengembangan IPTEKS. Yogyakarta: Direktorat Ketenagaan Direktorat Jenderal Pendidikan Tinggi Departemen Pendidikan Nasional.

Mulder, N. 2001. Mistisme Jawa: Ideologi di Indonesia. Yogyakarta: LKiS.

Nagel, S.S. 1982. Policy Evaluation: Making Optimum Decisions. New York, USA: Praeger Publisher.

Saaty, T.L. 1986. Decision Making for Leaders: The Analytical Hierarchy Process for Decisions in Complex World. Pittsburgh, USA: University of Pittsburgh.

Sastrapratedja, M. 1999. Peranan Agama dalam Era Globalisasi. Sumbangan Pemikiran Pokja II - DRN mengenai Beberapa Isu tentang Globalisasi. Jakarta: DRN.

Sirakaya, E. and R.W. McLellan. 1998. Modelling tour operators' voluntary compliance with ecotourism principles: A behavioral approach. Journal of Travel Research, 36 (winter): 42-55.

Smith, V. 1977. Host and Guest. Chicago, Philadelphia, USA: University of Pensylvania Press.

Steger, M. B. 2002. Globalisme: Bangkitnya ldeologi Pasar. Diterjemahkan oleh H. Prasetyo. Yogyakarta: Lafadi Pustaka.

UNESCO. 2007. Unesco Cultural Activities Worldwide. www. unesco.org

Watson, C.J., P. Ballingsley., D.J Croft., and D.V. Hundsberger. 1993. Statistic for Management and Economics. Englewood Cliffs, NJ, USA: Prentice Hall, Inc..

\footnotetext{
- Amiluhur Soeroso, adalah staff pengajar dan peneliti di Sekolah Tinggi Pariwisata API, Yogyakarta. Bidang minat penulis adalah ekonomika lingkungan dan ekonomika strategi. Y. Sri Susilo, adalah staff pengajar dan peneliti di Fakultas Ekonomi, Universitas Atma Jaya, Yogyakarta. Bidang minat penulis adalah dalam bidang ekonomika industri dan ekonomika strategi. Saran dan kritik yang membangun bisa langsung menghubungi penulis melalui email: yss@fe.uajy.ac.id dan amisoeroso@gmail.com.
} 